ROCZNIK PRZEMYSKI t. 57

HISTORIA z.1 (26) 2021

MALGORZATA SKOTNICKA-PALKA (Wroctaw)

orcid.org: 0000-0002-1284-7028

\title{
PROBLEMY OŚWIATY POZASZKOLNEJ W SCHYŁKU DWUDZIESTOLECIA MIĘDZYWOJENNEGO W ŚWIETLE MATERIAŁÓW ŹRÓDŁOWYCH INSPEKTORA SZKOLNEGO MIEJSKIEGO WE LWOWIE
}

\begin{abstract}
THE PROBLEMS OF EXTRACURRICULAR EDUCATION IN THE $2^{\text {ND }}$ HALF OF THE 1930S IN VIEW OF THE SOURCE MATERIALS OF THE MUNICIPAL SCHOOL INSPECTOR IN LVIV
\end{abstract}

The source materials by Jan Hipolit Majewski, the Municipal School Inspector in Lviv, present the plan of extracurricular work for 1936/1937, and also contain a report on the organization of the Folk High School in Lviv. They show the problems of adult education in the late twenties of the interwar period.

Key words: Jan Hipolit Majewski, adult education, extracurricular education.

Słowa kluczowe: Jan Hipolit Majewski, oświata dorosłych, edukacja pozaszkolna.

Po odzyskaniu przez Polskę niepodległości jednym z pierwszych zadań władz oświatowych było uregulowanie i ujednolicenie sytemu szkolnego, ustalenie jego organizacji, zadań, programów oraz podstaw ideowych. Równie istotną kwestią było upowszechnianie oświaty wśród osób dorosłych. W dwudziestoleciu międzywojennym system kierowania oświatą pozaszkolną miał trójstopniową strukturę. Najważniejszym ogniwem był Wydział Oświaty Pozaszkolnej Ministerstwa Wyznań Religijnych i Oświecenia Publicznego. W 1933 r. wprowadzono do inspektoratów szkolnych, czyli obwodowych władz szkolnych, inspektorów (instruktorów) oświaty pozaszkolnej. Problem kształcenia osób dorosłych był także obiektem zainteresowania Związu Polskiego Nauczycielstwa Szkół Powszechnych, który powołał i prowadził Wydział Oświaty Pozaszkolnej ${ }^{1}$. Co istotne, zarówno władzom państwowym jak i samorządowym nie

${ }^{1}$ J. Doroszewski, Rozwój życia oświatowego wśród dorostych na Zamojszczyźnie w latach 1918-1939, „Przegląd Historyczno-Oświatowy”, R. 42: 1999, nr 1/2, s. 116-117. 
udało się stworzyć podstaw prawnych do rozwijania pracy oświatowej wśród dorosłych. Dlatego też najważniejsze inicjatywy w tej dziedzinie podjęły organizacje społecz$n^{2}$. W omawianym okresie aktywne były trzy tego typu towarzystwa: Towarzystwo Czytelni Ludowych ${ }^{3}$ (dyrektorem był ks. Antoni Ludwiczak) ${ }^{4}$, Towarzystwo Szkoły Ludowej $^{5}$ (prezesem był dr Ernest Adam) ${ }^{6}$ oraz Polska Macierz Szkolna ${ }^{7}$ (kierowana przez Józefa Świeżyńskiego), które należały do Zjednoczenia Polskich Towarzystw Oświatowych ${ }^{8}$. Celem ZPTO było utworzenie w przyszłości jednego towarzystwa oświatowego obejmującego swoją działalnością obszar całej Polski9 .

Znaczącą rolę w kształceniu osób dorosłych w II RP odgrywały również uniwersytety ludowe. Były to autonomiczne placówki, których założenia oparto na wzorcach skandynawskich, prowadzono w oparciu o reguły samorządności. Mieściły się zazwyczaj we własnych budynkach, posiadały zwykle internaty i przynależne gospodarstwa rolne. Słuchacze kształcili się na cztero- lub pięciomiesięcznych kursach, na których panowała swoboda dyskusji i wymiany myśli. Funkcjonowały one w oparciu o dwa wzory: katolicki (zainicjowany przez ks. A. Ludwiczaka) oraz świecki (wypracowany przez inż. Ignacego Solarza) ${ }^{10}$.

${ }^{2}$ Historia wychowania wiek XX, red. J. Miąso, Warszawa 1980, s. 156.

${ }^{3}$ Towarzystwo Czytelni Ludowych - działające w latach 1880-1950, obejmowało swym zasięgiem Śląsk, Wielkopolskę, Pomorze, Warmię, Mazury, Dolny i Górny Śląsk. Jego celem było szerzenie oświaty wśród polskiej ludności, zakładanie bibliotek i czytelni, organizacja odczytów, [za:] Poznańskie Towarzystwo Przyjaciół Nauk, Rps 1178: Akta Okręgowego Towarzystwa Czytelni Ludowych w grodzisku Wlkp. Korespondencja ogólna z lat 1919-1935, k. 1.

${ }^{4}$ Zakład Narodowy im. Ossolińskich we Wrocławiu (dalej ZNiO), Rps ZNiO 13174/II/3, Mf. 2739: J. Kornecki, Wspomnienia i szkice. Moje wspomnienia i moja wieś rodzinna 1884-1944, s 357-362.

${ }^{5}$ Towarzystwo Szkoły Ludowej - powołane w 1891 r. na terenie Galicji, zaś po 1918 r. działające w południowej i wschodniej części II RP. Jego celem było organizowanie kursów dla dorosłych analfabetów, tworzenie i prowadzenie domów oświatowych i ludowych - szczególnie dla mieszkańców wsi, organizacja szkoleń zawodowych dla dorosłych, kursów dokształcających dla pracowników oświatowych. Zakładało domy ludowe, biblioteki, bursy i ochronki. Prowadziło działalność do 1940 r., [za:] M.W. Wanatowicz, Ludność napływowa na Górny Śląsk w latach 1922-1939, Katowice 1982, s. 78.

${ }^{6}$ J. Kornecki, op. cit., s. 357-362.

${ }^{7}$ Polska Macierz Szkolna - działa w latach 1905-1940 w celu krzewienia i popierania oświaty w duchu chrześcijańskim i narodowym poprzez zakładanie i prowadzenie ochronek, szkół ludowych, seminariów nauczycielskich, bibliotek i czytelni ludowych, [za:] K. Wierzyński, Pamiętnik poety, Warszawa 1991, s. 55-56; I. Matejukowa, Oświata w latach odzyskania niepodległości, [w:] Warszawa w pierwszych latach niepodległości, pod red. M.M. Drozdowskiego i H. Szwankowskiej, Warszawa 1998, s. 149.

${ }^{8}$ Zjednoczenie Polskich Towarzystw Oświatowych utworzyły następujące organizacje: Towarzystwo Czytelni Ludowych w Poznaniu, Towarzystwo Szkoły Ludowej w Krakowie, Polska Macierz Szkolna w Warszawie, Polska Macierz Szkolna Ziem Wschodnich z siedzibą w Wilnie, Polska Macierz Szkolna w Gdańsku, Macierz Szkolna Śląska Cieszyńskiego. W późniejszym czasie akces do tej federacji zgłosiło także Towarzystwo im. Piotra Skargi w Krakowie, Towarzystwo Pomocy Polakom za Granicą im. Adama Mickiewicza, Towarzystwo „Opieka Polska nad Rodakami na Obczyźnie” z władzami w Warszawie oraz Stowarzyszenie Chrześcijańsko-Narodowego Nauczycielstwa Szkół Powszechnych, [za:] G. Michalski, Kierunki zaangażowania Jana Korneckiego w prace zjednoczeniowe polskich towarzystw oświatowych 1923-1935, „Studia Edukacyjne”, 2018, nr 48, s. 161.

${ }^{9}$ J. Kornecki, op. cit., s. 357-362.

${ }^{10}$ Historia wychowania ..., s. 156-157, 163-166. 
Istotną kwestią w dziedzinie edukacji dorosłych było również kształcenie pracowników oświatowych, w tym instruktorów oświaty pozaszkolnej, nauczycieli pracujących z dorosłymi, organizatorów życia kulturalnego i bibliotekarzy. Doskonaleniu ich kompetencji służyły: kursy (roczne i dwuletnie), konferencje oświatowe, wydawnictwa teoretyczne i metodyczne, podręczniki czy czasopisma. Prace w tym kierunku podejmował m.in.: Instytut Oświaty Dorosłych czy Studium Pracy Społeczno-Oświatowej Wolnej Wszechnicy Polskiej ${ }^{11}$.

Podstawowym problemem oświaty pozaszkolnej we Lwowie był brak odpowiedniej wysokości funduszy na realizację szczegółowych planów opracowanych przez obwodowego inspektora oświaty pozaszkolnej Jana Hipolita Majewskiego ${ }^{12}$. Sytuację tę odzwierciedlają prezentowane źródła pochodzące ze zbiorów rękopiśmiennych Zakładu Narodowego im. Ossolińskich we Wrocławiu. Zespół liczy 764 strony i obejmuje materiały dotyczące bieżącej działalności J.H. Majewskiego m.in.: plany pracy oświaty pozaszkolnej i sprawozdania z lat 1934-1939; notesy zawierające odręczne wpisy J.H. Majewskiego dotyczące jego pracy zawodowej; sprawozdania roczne (ogólne i szczegółowe) ze stanu pracy społeczno-oświatowej Kuratorium Okręgu Szkolnego Lwowskiego - Oddziału Oświaty Pozaszkolnej. Dodatkowo zawiera m.in.: sprawozdania roczne z działalności władz szkolnych w zakresie oświaty pozaszkolnej (przeznaczone ściśle do użytku wewnętrznego władz szkolnych); tezy do referatów opracowane przez Obwodowych Instruktorów Oświaty Pozaszkolnej (np. w Łodzi, Krakowie, Warszawie, Katowicach); wzór zaświadczenia ukończenia Kursów Wieczorowych Oświaty Pozaszkolnej.

W tekstach zachowano oryginalną pisownię, interpunkcję, ortografię oraz układ graficzny.

\section{Źródło $1^{13}$ \\ Plan pracy oświatowej na rok 1936/1937 autorstwa Jana Hipolita Majewskie- go, obwodowego inspektora oświaty pozaszkolnej w Inspektoracie Szkolnym Miejskim we Lwowie z 13 XI 1936 roku.}

Inspektorat Szkolny Miejski

we Lwowie, ul. Bourlarda 2/11

Nr: 5048/36

13 XI 1936

Plan pracy oświatowej na rok 1936/1937

Praca oświatowa pozaszkolna we Lwowie w odróżnieniu od innych miast nie opiera się o żadne subwencje ze strony władz samorządowych. Wskutek tego pewne formy

${ }^{11}$ Ibidem, s. 161.

${ }^{12} \mathrm{ZNiO}$, Rps ZNiO 17238 II: Materiały Jana Hipolita Majewskiego dotyczace oświaty pozaszkolnej we Lwowie z lat 1934-1939.

${ }^{13}$ Ibidem, s. 9-17. 
pracy, wymagające większych i stałych dotacji, na terenie Lwowa nie mogły się rozwinąć. Takie instytucje oświatowe jak Samorządowa miejska biblioteka publiczna, Uniwersytet Powszechny lub sieć, racjonalnie rozmieszczonych kursów wieczornych o[świty] p[ozaszkolnej] są nieznane dotychczas we Lwowie, chociaż istnieją od dawna i spełniają swoje zadanie w miastach o wiele mniejszych nie mających takich jak Lwów tradycyj i aspiracyj ${ }^{14}$ kulturalnych.

\section{Starania o subwencje.}

Z powyższego wynika, że najpilniejszym zadaniem moim w przyszłości będą usilne starania o zdobycie i zapewnienie sobie funduszów, któreby umożliwiały jak najpełniejsze zrealizowanie postulatów, objętych niniejszym planem pracy.

\section{Uniwersytet Powszechny ${ }^{15}$.}

Na czoło potrzeb kulturalnych miasta wysuwa się sprawa uniwersytetu powszechnego, któreby - jak w innych miastach Polski - spełniał swą rolę dla najszerszych warstw mieszkańców, zwłaszcza na peryferiach. Poczyniłem już w tym kierunku wszelkie prace i doświadczenia innych tego typu Uniwers[tetów] Powsz[echnych] w kraju, wystarałem się na ten cel o subwencję Zarządu Miejskiego oraz przygotowałem pomieszczenia dla trzech oddziałów U[niwersytetów] P[owszechnych] /Lewandówka ${ }^{16}$ - Zamarstynów ${ }^{17}$ - Łyczaków ${ }^{18} /$. Uruchomienie tych placówek zależne jest zatem wyłącznie od wyasygnowania przyznanej przez Zarząd Miejski kwoty.

\section{Kursy wieczorowe o[świty] p[ozaszkolnej].}

Palącą potrzebą jest stworzenie kilkunastu kursów wieczorowych o[świty] p[ozaszkolnej] dla analfabetów i półanalfabetów rozsianych szczególnie na peryferiach wielkiego Lwowa. /Według powszechnego spisu ludności z $1931{ }^{19}$ roku Lwów posiada $8,5 \%$ analfabetów/. Jest to tem konieczniejsze, że „Koło Pań” T[owarzystwa] S[zkoły] L[udowej], pracujące na tym polu obejmuje swą skromną działalnością zaledwie śródmieście i nie wykazuje tendencji rozszerzenia pracy na dzielnice, położone na krańcach miasta. Urzeczywistnienie tych zamierzeń uzależnione jest również od koniecznych funduszów.

\footnotetext{
${ }^{14}$ Tradycji i aspiracji.

${ }^{15}$ Uniwersytet Powszechny - instytucja oświatowa, której celem była popularyzacja wiedzy przez systematyczne nauczanie w zespołach (wykłady ujęte w cykle i luźne odczyty), organizowanie samokształcenia i czytelnictwa, a także rozwijanie aktywności kult. wśród szerokich kręgów społeczeństwa. W II RP uniwersytecie powszechnym były zakładane przez samorządowe władze lokalne i stowarzyszenia oświatowe, np. TSL, TUR, [za:] https://encyklopedia.pwn.pl/haslo/uniwersytet-powszechny;3991441.html [dostęp: 19.06.2021].

${ }^{16}$ Osiedle w granicach Lwowa od $1930 \mathrm{r}$.

${ }^{17}$ Dzielnica Lwowa od $1931 \mathrm{r}$.

${ }^{18}$ Dzielnica Lwowa.

${ }^{19}$ Drugi powszechny spis ludności z dn. 9.XII 1931 r. Mieszkania i gospodarstwa domowe. Ludność. Stosunki zawodowe. Miasto Lwów, „Statystyka Polski”, Seria C, z. 58, Główny Urząd Statystyczny Rzeczypospolitej Polskiej, Warszawa 1937, [za:] http://mbc.cyfrowemazowsze.pl/ dlibra/docmetadata?id=14189\& from=publication [dostęp: 17.06.2021].
} 


\section{Miejska Biblioteka Publiczna.}

Również pilną i ważną jest sprawa uruchomienia miejskiej biblioteki publicznej z książek, będących własnością miasta a nie udostępnionych dotąd ludności, która napotyka na poważne trudności w pracy samokształceniowej. Istniejące biblioteki naukowe mają charakter ekskluzywny, biblioteki zaś handlowe, obliczone na zysk, nie spełniają zadania wychowawczego, a istniejąca Książnica T[owarzystwa] S[zkoły] L[udowej] nie może sprostać ogromowi zadania. Sprawą tą zainteresowałem odpowiednie czynniki i w przyszłości dołożę wszelkich starań by Zarząd Miejski skłonić do szybkiego uruchomienia biblioteki wraz z czytelnią. Sprawa staje się tym pilniejsza, że biblioteka ta miałaby w przyszłości zaopatrywać w książki słuchaczy U[niwerystetów] P[owszechnych], którzy korzystaliby nadto z czytelni książek i czasopism.

\section{Sekcja prelegentów.}

Liczne organizacje społeczne i kulturalnooświatowe odczytują brak bezinteresownych pracowników oświatowych a zwłaszcza prelegentów i zgłaszają u mnie swe zapotrzebowania w tym kierunku. W związku z tym, wyłania się potrzeba utrzymania Sekcji Prelegentów, któraby stanowiła stałą kadrę bezinteresownych pracowników, którymi dysponowałaby w miarę potrzeby. Stworzenie tej sekcji umożliwiłoby w porozumieniu z organizacjami rozwinięcie ożywionej akcji odczytowej na terenie wielkiego Lwowa, a pośrednio także innych form pracy oświatowej. Do dyspozycji sekcji prelegentów należałoby oddać koniecznie pomoce, a zwłaszcza epidiaskop, na którego zakupienie winny znaleźć się potrzebne fundusze.

\section{Bibliotekarstwo i czytelnictwo. Dokształcanie bibliotekarzy.}

W związku z badaniami nad stanem bibliotekarstwa oświatowego i czytelnictwa we Lwowie stwierdziłem, że olbrzymia większość prowadzących biblioteki nie posiada dostatecznych wiadomości w tym zakresie. Aby dokształcić czynnych bibliotekarzy, urządziłem informacyjny kurs bibliotekarski. Z pośród zgłoszonych tylko część mogła być przyjęta, tak, że wyłania się konieczność rychłego urządzenia kursów dla reszty zgłoszonych.

Celem ustawicznego dokształcenia przeszkolonych już bibliotekarzy zamierzam zwoływać stale miesięczne zebrania informacyjne $\mathrm{z}$ aktualnymi referatami specjalistów na temat czytelnictwa, nowych wydawnictw itp., połączonych z wycieczkami i dyskusją. Dzięki tej akcji dokształceniowej działalność bibliotek organizacji społecznych, oświatowych i zawodowych stanie się bardziej celową i skuteczną.

\section{Biblioteki i czytelnie dla młodzieży.}

Aby udostępnić młodzieży w wieku poszkolnym dobrą książkę i wychować ją na przyszłych konsumentów literatury, mam zamiar zorganizować w kilku punktach miasta biblioteki połączone z czytelniami dla młodzieży, która wypełniła obowiązek szkolny. 
Biblioteka o[świty] p[ozaszkolnej] w I[nspektoracie] S[zkolnym] M[iejskim]. W miarę posiadanych funduszów mam w planie powiększenie i skompletowanie księgozbioru o[świty] p[ozaszkolnej] w I[nspektoracie] S[zkolnym] M[iejskim]. tak abym mógł zaspokoić potrzeby działaczy oświatowych we Lwowie.

\section{Cykl odczytów w centrum miasta.}

Zgodnie z życzeniami przystąpię w najbliższym czasie do zorganizowania cyklu odczytów w których niezależnie od innych rodzajów pracy oświatowych - poruszy się szereg zagadnień aktualnych, interesujących zwłaszcza ogół działaczy społecznych i oświatowych. Odczyty będą odbywać się w śródmieściu.

\section{Świetlice powszechne.}

W miarę sprzyjających warunków rozszerzę agendy oświaty pozaszkolnej na peryferiach, gdzie obok kursów wieczorowych o[świty] p[ozaszkolnej] i oddziałów uniwersytetu powsz[echnego] planuję utworzenie dla poszczególnych dzielnic miasta kilku świetlić powszechnych, któreby skupiały rzesze niezorganizowanej młodzieży i stały się ogniskiem pracy samokształceniowej.

\section{Wycieczki.}

W planie pracy na przyszłość uwzględni się również organizację wycieczek celem bieżącego poznania miasta, jego zabytków kulturalnych i historycznych oraz warsztatów pracy, ewentualnie wycieczek krajoznawczych w bliższe i dalsze okolice Lwowa.

Kursy wieczorowe o[światy] p[ozaszkolnej] Koła Pań T[owarzystwa] S[zkoły] L[udowej], Koła Grunwaldzkiego T[owarzystwa] S[zkoły] L[udowej]. Szkoły wiecz[orowej] Z[wiązku] N[auczycielstwa] P[olskiego]. Pocz[ątkowe] Szk[oły] Żołn[nierskie] Zespoły d[o]b[rego] cz[ytania] k[siążek] i samokształceniowe.

Prócz tego - jak dotąd - opiekować się będę kursami wieczorowymi o[świty] p[ozaszkolnej] Koła Pań T[owarzystwa] S[zkoły] L[udowej], Koła Grunwaldzkiego T[owarzystwa] S[zkoły] L[udowej], początkowymi szkołami żołnierskimi, szkołami wieczorowymi Z[wiązku] N[auczycielstwa] P[olskiego]. Szczególnych starań dołożę również, aby wzbudzić zainteresowanie dla zespołów dobrego czytania i zespołów samokształceniowych wśród członków organizacyj młodzieżowych. Spodziewam się, że realizacji niniejszego dość skromnego programu prac na najbliższą przyszłość, nie natrafi na nieprzyzwyciężone przeszkody, o ile tylko czynniki zainteresowane użyczą pomocy finansowej i poparcia.

Lwów, 13/XI 1936 r.

Dr. Jan Majewski Obwod[owy] Inspektor O[światy] P[ozaszkolnej] 
$* \quad * \quad *$

\section{Źródło $2^{20}$}

\section{Sprawozdania okresowe Jana Majewskiego obwodowego Inspektora Oświaty Pozaszkolnej (fragmenty).}

Inspektorat Szkolny Miejski

we Lwowie, ul. Bourlarda 2/11

Nr: 2122/36

Sprawozdanie okresowe

Obwodowego Inspektora Oświaty Pozaszk.za okres od 1.XI.1935 do 1.II.1936

W okresie sprawozdawczym z prac poważniejszych podjąłem starania dokoła zorganizowania Uniwersytetu Powszechnego, który miał służyć jednostkom skupionym $\mathrm{w}$ organizacjach tak też szerokim, niezrzeszonym warstwom. W czasie kilku indywidualnych konferencji zainteresowałem tą palącą sprawą kierowników organizacji: Zw. Rezerwistów, Zw. Strzelecki, TSL, Organizacja Młodzieży Pracującej. Przekonawszy ich o tem, jak ważną i pilną jest sprawa powołania do życia tej instytucji, na którą dotąd Lwów nie potrafił się zdobyć, skolei wypracowałem plan organizacji Uniwersytetu. Czas studiów wyznaczono w programie na trzy lata, przyczem grono prelegentów miało być stałe, co umożliwiałoby skuteczniejszą pracę. Wyszukałem odpowiedniego kierownika, w osobie prof. Wojtowicza, który dobrał odpowiednich współpracowników i opracował z nimi rozkład materiału dla poszczególnych zagadnień przewidzianych w programie przyszłego Uniwersytetu.

Celem ostatecznego omówienia i uzgodnienia szczegółów organizacyjnych odbyła się wspólna konferencja w Oddziale Oświaty Pozaszkolnej w Kuratorium O[kręgu] S[zkolnego] Lw[owskiego] [...] Ustalono przewidywane koszty rocznego utrzymania tej placówki w wysokości 2.500 do 3.000 złotych i wyłoniono delegację do prezydenta miasta Drojanowskiego ${ }^{21}$ : miała ona wyjednać odpowiednią subwencję z funduszów miejskich. Po załatwieniu przeze mnie licznych związanych z tem formalności, audjencja doszła do skutku w dniu 27 listopada 1935 r. Prezydent Drojanowski ustosunkował się do projektu z rezerwą, obiecując pod pewnymi warunkami poprzeć sprawę przy układaniu przyszłego budżetu miejskiego /1936/37/. Wobec tego zebrali się ponownie kierownicy organizacji w biurze Inspektoratu i oświadczyli, że po porozumieniu się ze swoimi Zarządami postarają się przyczynić materialnie do uruchomienia Uniwersytetu jeszcze w bie$\dot{z}[a ̨ c y m]$ roku. Ponieważ organizacje nie dawały jednak gwarancji, że wywiążą się ściśle z przyjętych na siebie ewentualnie zobowiązań finansowych, oświadczył

\footnotetext{
${ }^{20}$ Materiaty Jana Hipolita Majewskiego ..., s. 87-89.

${ }^{21}$ Wacław Drojanowski - prezydent Lwowa od 27 listopada 1931 do marca 1936 roku.
} 
prof. Wojtowicz, że nie mając do dyspozycji zagwarantowanych funduszów nie podejmie się proponowanego mu kierownictwa.

W tym stanie rzeczy, nie mogąc Uniwersytetowi dostarczyć bezinteresownych pracowników ani dać mu trwałych podstaw finansowych, nie chciałem wziąć na siebie odpowiedzialności za jego losy. Nie zrezygnowałem jednak i dalej będę kontynuował rozpoczęte starania, szczególnie w kierunku otrzymania funduszów z Zarządu Miejskiego. [...].

\author{
Dr. Jan Majewski H[ipolit] \\ Obwodowy Inspektor O[światy] P[ozaszkolnej]
}

\title{
Bibliografia
}

\section{Źródła archiwalne:}

Poznańskie Towarzystwo Przyjaciól Nauk:

Rps 1178: Akta Okręgowego Towarzystwa Czytelni Ludowych w grodzisku Wlkp. Korespondencja ogólna z lat 1919-1935.

\section{Zaklad Narodowy im. Ossolińskich we Wroclawiu:}

Rps 13174/II/3, Mf. 2739: J. Kornecki., Wspomnienia i szkice. Moje wspomnienia i moja wieś rodzinna 1884-1944.

Rps 17238 II: Materiały Jana Hipolita Majewskiego dotyczace oświaty pozaszkolnej we Lwowie z lat 1934-1939.

\section{Źródła drukowane:}

K. Wierzyński, Pamiętnik poety, Warszawa 1991.

\section{Opracowania:}

J. Doroszewski, Praca oświatowa i kulturalna na Lubelszczyźnie w latach II Rzeczypospolitej, Lublin 1995.

J. Doroszewski, Rozwój życia oświatowego wśród dorostych na Zamojszczyźnie w latach 1918-1939, „Przegląd Historyczno-Oświatowy”, R. 42: 1999, nr 1/2, s. 115-129.

J. Dzieniakowska, Prasa radomska w dwudziestoleciu międzywojennym, Radom 1995.

Historia wychowania wiek XX, red. J. Miąso, Warszawa 1980.

I. Matejukowa, Oświata w latach odzyskania niepodlegtości, [w:] Warszawa w pierwszych latach niepodległości, pod red. M.M. Drozdowskiego i H. Szwankowskiej, Warszawa 1998.

G. Michalski, Kierunki zaangażowania Jana Korneckiego w prace zjednoczeniowe polskich towarzystw oświatowych 1923-1935, „Studia Edukacyjne”, 2018, nr 48, s. 151-168.

J. Nowak, A. Cieślak A., Edukacja dorostych w Polsce i na świecie, Warszawa 1982.

M.W. Wanatowicz, Ludność naptywowa na Górny Śląs w latach 1922-1939, Katowice 1982. 